\title{
Number of Fetuses
}

National Cancer Institute

\section{Source}

National Cancer Institute. Number of Fetuses. NCI Thesaurus. Code C124626.

A measurement of the total number of fetuses, which includes alive and dead fetuses, present in the uterus. 